\title{
Embryonic Toxico-pathological Effects of Origanum vulgare: Evaluation of the Gross and Histopathological Lesions using a Chick Embryo Model
}

\author{
Amin Derakhshanfar ${ }^{1,2 \mathbb{D}}$, Hadi Tavakkoli ${ }^{3 *}$, Ali Poostforoush Fard ${ }^{4}$, Javad Moayedi ${ }^{1 \oplus}$ \\ 1. Diagnostic Laboratory Sciences and Technology Research Center, School of Paramedical Sciences, Shiraz University \\ of Medical Sciences, Shiraz, Iran \\ 2. Center of Comparative and Experimental Medicine, Shiraz University of Medical Sciences, Shiraz, Iran \\ 3. Dept. of Clinical Sciences, Faculty of Veterinary Medicine, Shahid Bahonar University of Kerman, Kerman, Iran \\ 4. Vice-Chancellery for Research Affairs, Shiraz University of Medical Sciences, Shiraz, Iran
}

\begin{tabular}{|c|}
\hline Article Info \\
\hline doi) \\
\hline $\begin{array}{c}\text { Received: 2018/12/31; } \\
\text { Accepted: 2019/02/26; } \\
\text { Published Online: 22 June 2019; }\end{array}$ \\
\hline
\end{tabular}

Use your device to scan and read the article online

Corresponding Information:

Hadi Tavakkoli, Dept. of Clinical Sciences,

Faculty of Veterinary Medicine, Shahid

Bahonar University of Kerman, Kerman,

Iran

Email: tavakkoli@uk.ac.ir

\begin{abstract}
Background \& Objective: Toxico-pathological effects of herbal plants have always been a major concern, but little information is provided on the toxicopathological effects of origanum on the fetus. Due to ethical rules and regulations, no drug experiment on the human fetus is permitted; hence, the chick embryo model is used as an ideal opportunity to study the adverse effects of drugs. This study aims to assess the histopathological effects of the various doses of Origanum vulgare ( $O$. vulgare) using the chick embryo model.
\end{abstract}

Materials \& Methods: Ross chicken eggs were subjected into four experimental groups ( $\mathrm{n}=7)$; phosphate buffered saline-injected group and Origanum-injected groups that were treated with $O$. vulgare leaf-extract at doses of 25,50 , and $100 \mathrm{mg}$ per kg eggweight, respectively. After injecting the embryos with the extracts, re-incubation was performed and allowed to develop until day 18, when embryos were evaluated for pathological lesions.

Results: Treated embryos were normal in the Origanum-injected groups and no defect was noticed on the body features. The microscopic lesions including congestion and edema were made in the brain, liver, kidney, heart, and lung in a dosedependent manner.

Conclusion: It can be concluded that $O$. vulgare at a concentration higher than 25 $\mathrm{mg}$ per $\mathrm{kg}$ is toxic for chick embryo in a dose-dependent manner; therefore, more attention should be given to the toxicity of $O$. vulgare in the period of fetal development.

Keywords: Chick, Embryo, Fetus, Origanum vulgare, Pathology

\section{Introduction}

The ever increasing demand to treat emergenic diseases has led to the idea of finding new medicine, and herbal drugs have produced promising results (1-3). The Origanum vulgare (O. vulgare), of the family Lamiales grows in many parts of the world. Its medicinal properties include antioxidant, antiemetic, anti-inflammatory, anticancer, anti-fungi, anti-yeast, anti-viral, antimicrobial, larvicidal, enzyme inhibition, and cytotoxic activities (4-6). Today, it is often utilized to treat cardiac diseases, analgesia, atherosclerosis, wound healing, and human skin diseases (7-10). Recent researches indicated that it can destroy some micro-organisms like Escherichia coli, Klebsiella oxytoca, Staphylococcus aureus, Salmonella, and Shigella (11-13). However, like many other drugs and herbal medicines, Origanum has some side effects, such as allergic reactions, alteration in iron absorption, anticoagulant activities, thymol toxicity, and gastrointestinal symptoms $(14,15)$.

Many researches were conducted to prepare a different type of Origanum by products, such as extract, edible jelly and powder. The present study performed to evaluate the toxic effects of the Origanum leaves on the chick embryo. Due to its availability and easy manipulation as well as its embryogenesis similarity to human beings, chick embryo has become an attractive model to study the developmental processes (16-21).

\section{Materials and Methods}

This experimental study was approved by the local Ethics Committee of Shiraz University of Medical Sciences (November15, 2014 - Approval no.IR.SUMS. REC.1393.8050). 


\section{Herbal Plant Extract}

The $O$. vulgare leaves were purchased from the Gyahan Darooi Company, Kerman, Iran on October 2015 and authenticated at the Department of Pharmacological Sciences of Kerman University, Kerman, Iran. Traditional Soxhlet extraction was carried out in a standard apparatus $(22,23)$. For 4 hours, $100 \mathrm{~g}$ of $O$. vulgare leaves were soaked in $1000 \mathrm{~mL}$ of solvent (water/ethanol 80/20v/v). The extracts were filtered via filter paper and the remaining volume was completely dried in an atmospheric oven at $60^{\circ} \mathrm{C}$.

\section{Drug Administration to the Chick Embryos}

A total of 28 fertile chicken eggs (Ross 308) with an average egg-weight of $54.8 \pm 0.5 \mathrm{~g}$ were supplied by the Mahan Breeder Company, Kerman, Iran and randomly assigned into four equal treatment groups $(n=7)$. Fertilized chicken eggs were placed at $37.5^{\circ} \mathrm{C}$ and $60 \%$ relative humidity in a humidified incubator (Belderchin Damavand Co. PLC-DQSH, Tehran, Iran). Experiments were performed on chick embryos until day 18 of the embryonic growth. All treatments were administered as $0.5 \mathrm{~mL} / \mathrm{egg}$ of a single dose into the yolk sac of each egg. On the $4^{\text {th }}$ day of the embryonic growth, phosphate buffered saline (group 1) or $O$. vulgare leaves-extract at doses of 25 (group 2), 50 (group 3) or 100 (group 4) mg per $\mathrm{Kg}$ egg weight, were injected into each group of fertilized chicken eggs, as described previously $(20,21$, 24-26). Before injection, the extracts were filtered through a syringe filter $(0.22 \mu \mathrm{m})$ to remove any micro-organism.

\section{Assessment of Pathological Lesions}

Embryos were investigated for gross and histopathological injures on the $18^{\text {th }}$ day of the growing period. At first, embryos were killed by chilling and then examined under the stereo-microscope to study any gross lesions $(27,28)$. The brain, liver, kidneys, heart, and lungs were fixed in $10 \%$ neutral buffered formalin to prepare paraffin-embedded tissues, and then stained with hematoxylin and eosin.

\section{Measurements}

The body length and weight of the embryo was calculated via scale (Limestone AT-p735, Iran, range 100 $\mathrm{g}$ to $\pm 0.01 \mathrm{~g}$ ) and caliper (Mitutoyo-500, Japan, range $0.01 \mathrm{~mm}$ ). The length was measured from front angle of the head to the apex of the tail (uropygial gland).

\section{Statistical Analysis}

Statistical analysis was done via SPSS 20 (SPSS Inc., Chicago, IL., USA). The Statistical tests including Fisher's exact test, One-way analysis of variance, and Tukey's tests were used to evaluate the significant among treatment groups. A P-value $<0.05$ was considered significant.

\section{Results}

\section{Macroscopic Findings}

The embryos of all experimental and control groups were normal. There was no abnormality on the external body limbs (Figure 1).

\section{Microscopic Findings}

In group 2, all the tissues were normal and no microscopic changes were observed (Figure 2). In the embryos of group 3, congestion was seen in the brain, liver, kidneys, heart, and lungs. In the brain and lungs, edema was also seen (Figure 3 ).

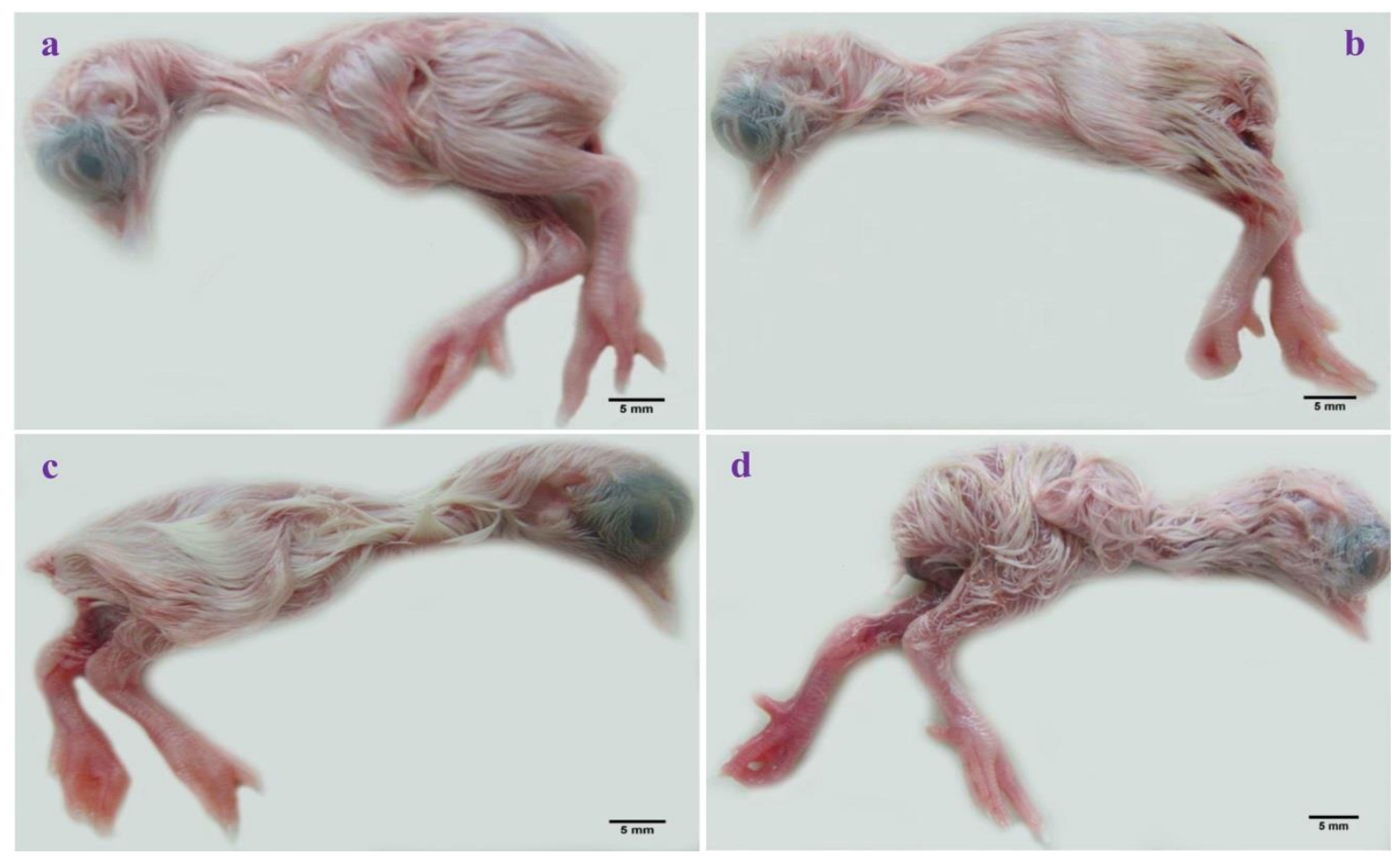


Figure 1. The chick embryos treated with phosphate buffered saline (a), $25 \mathrm{mg} / \mathrm{Kg}$ egg-weight of $O$. vulgare leaf-extract (b), $50 \mathrm{mg} / \mathrm{Kg}$ egg-weight of $O$. vulgare leaf-extract (c), and $100 \mathrm{mg} / \mathrm{Kg}$ egg-weight of $O$. vulgare leaf-extract (d) are normal with no gross abnormality on the body surface.

The lesions in the brain, liver, kidneys, heart, and lungs in the embryos of group 4 were the same as group 3, but the brain edema was much more severe (Figure 4). No microscopic injures were evident in the control embryos.
Finally, no significant difference was observed in the embryo weight and the embryo length of the groups that were treated with an $O$. vulgare leaves-extract compared to the control group (Table 1).

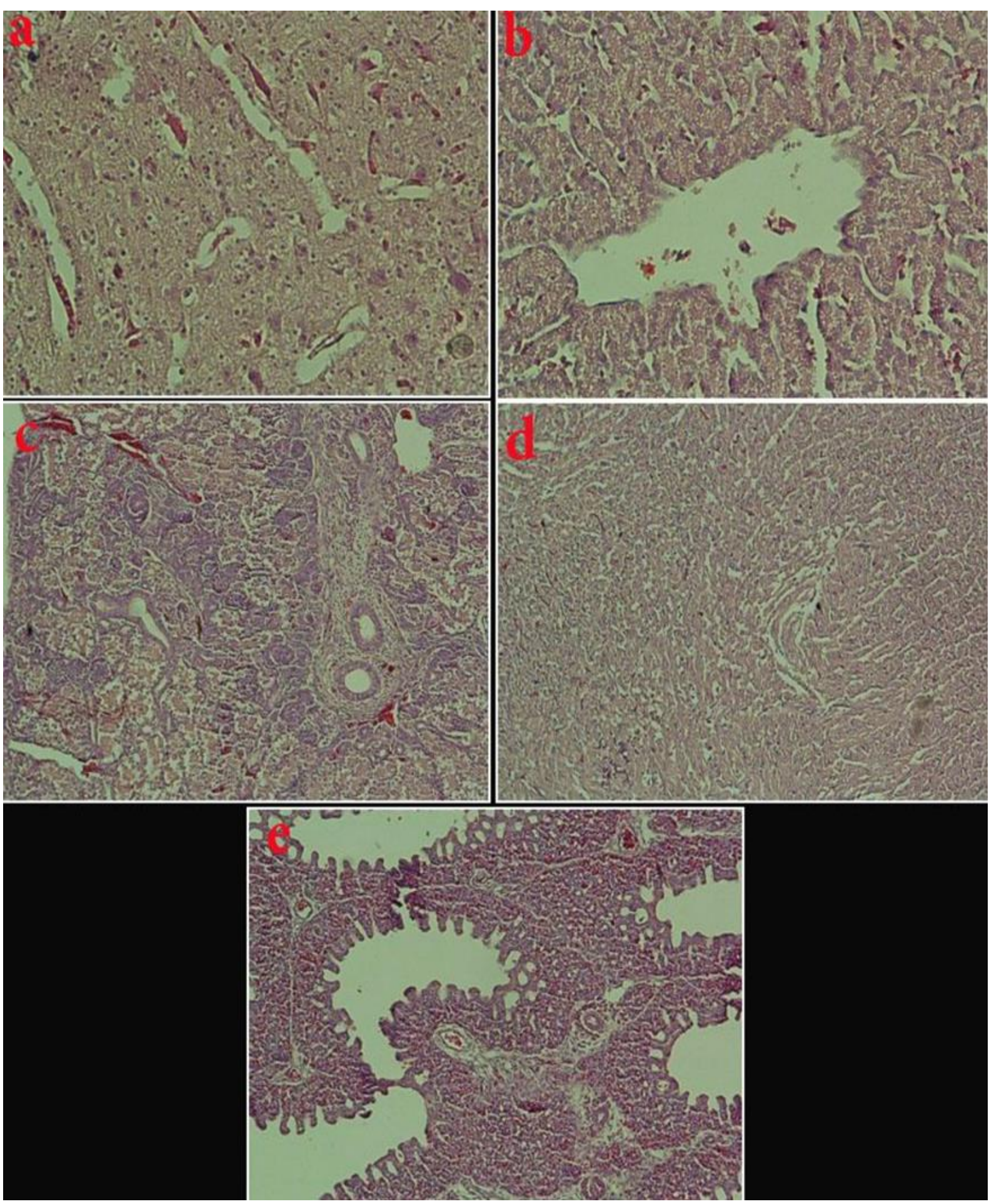

Figure 2. Photomicrograph of the chick embryo treated with $25 \mathrm{mg} / \mathrm{Kg}$ egg-weight of $O$. vulgare leaf-extract. (a) Normal structure of the brain is seen $(\times 200, \mathbf{H} \& E)$, (b) Normal structure of the liver is seen $(\times 200, \mathbf{H} \& \mathrm{E})$, (c) Normal structure of 
the kidney is seen $(\times 100, \mathrm{H} \& \mathrm{E})$, (d) Normal structure of the heart is seen $(\times 100, \mathrm{H} \& \mathrm{E})$, (e) Normal structure of the lung is seen $(\times 100$, H\&E).

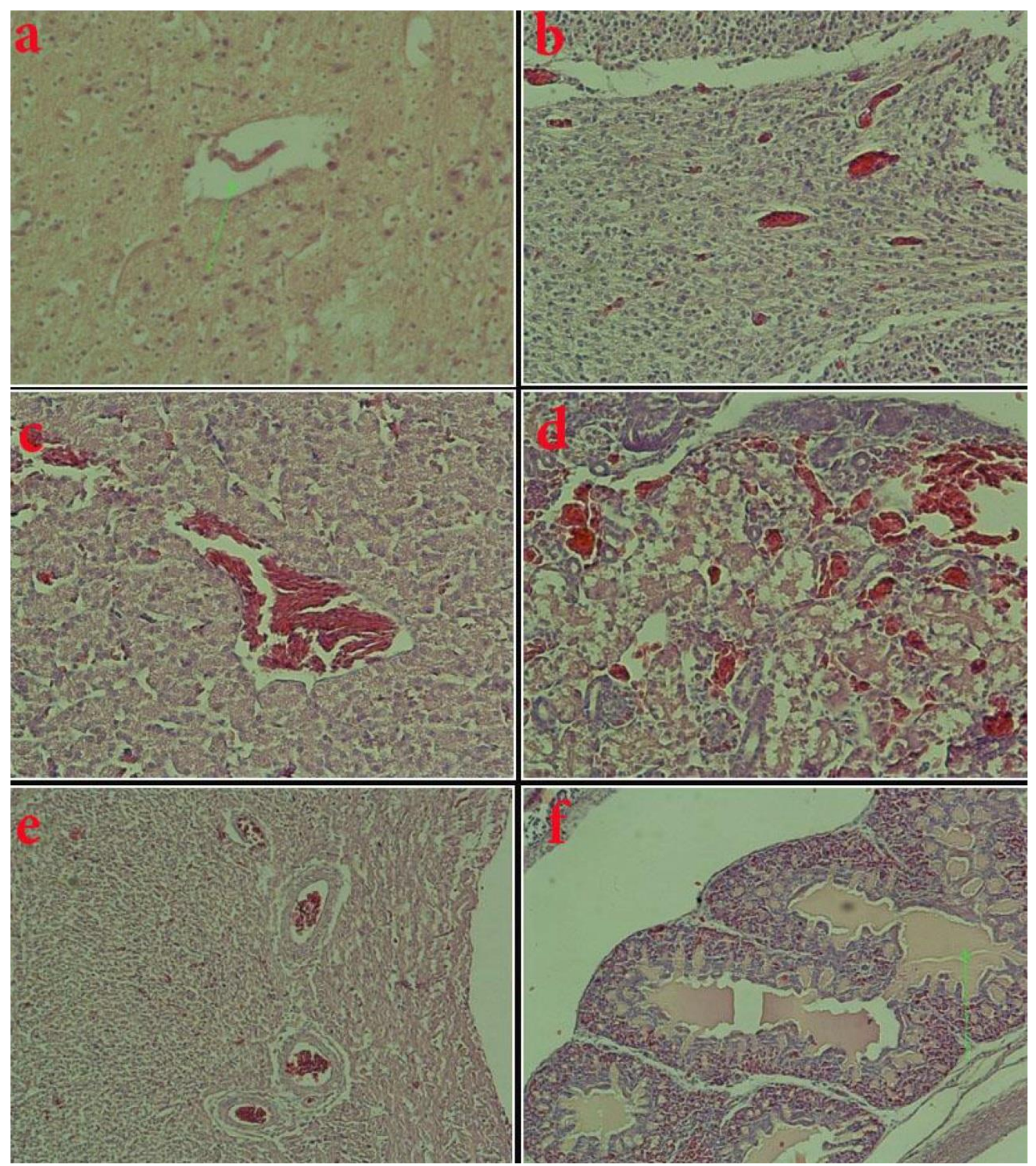

Figure 3. Photomicrograph of the chick embryo treated with $50 \mathrm{mg} / \mathrm{Kg}$ egg-weight of $O$. vulgare leaf-extract. (a) Dilation of the Virchow- Robin space (arrow) is seen in the brain $(\times 200, H \& E),(b)$ Congestion is seen in the brain $(\times 200, H \& E)$,

(c) Congestion is seen in the liver $(\times 200, \mathrm{H} \& \mathrm{E}),(\mathrm{d})$ Renal congestion is seen $(\times 200, \mathrm{H} \& \mathrm{E})$, (e) Congestion is seen in the heart $(\times 100, \mathrm{H} \& \mathrm{E})$, (f) Pulmonary edema (arrows)is seen $(\times 100, \mathrm{H} \& \mathrm{E})$.

Table 1. Effect of in-ovo injection of $O$. vulgare leaf-extract on embryo-weight/egg-weight and the body length of the chick embryo

\begin{tabular}{lccc} 
& \multicolumn{3}{c}{$\begin{array}{c}\text { O. vulgare injected group } \\
\text { (mg/Kg egg-weight) }\end{array}$} \\
Control group & \multicolumn{3}{c}{100} \\
\end{tabular}




$\begin{array}{cccccc}\text { Embryos weight / egg-weight (g) } & 0.75 \pm 0.11 & 0.75 \pm 0.23 & 0.74 \pm 0.89 & 0.57 \pm 0.16 & >0.05 \\ \text { Body length (mm) } & 78.45 \pm 4 & 77.87 \pm 6 & 77.73 \pm 7 & 77.54 \pm 5 & >0.05\end{array}$

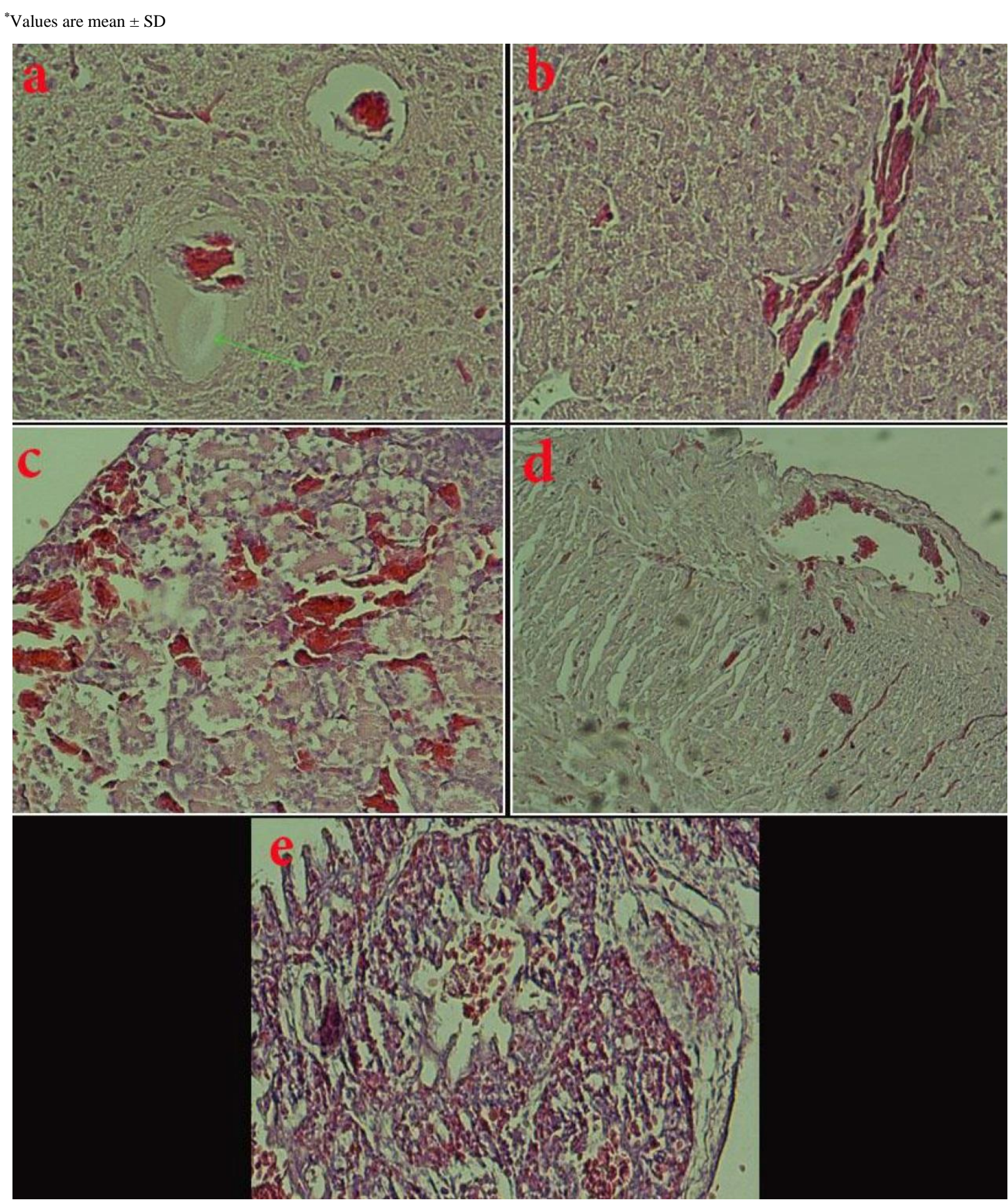

Figure 4. Photomicrograph of the chick embryo treated with $100 \mathrm{mg} / \mathrm{Kg}$ egg-weight of $O$. vulgare leaf-extract. (a) Congestion and edema in Virchow- Robin space (arrow) are seen in the brain $(\times 100, H \& E)$, (b) Severe congestion is seen in the liver $(\times 200, \mathrm{H \& E}),(\mathrm{c})$ Severe congestion is seen in the kidney $(\times 100, \mathrm{H \& E}),(\mathrm{d})$ Severe congestion is seen in the heart $(\times 100, H \& E)$, (e) Severe congestion is seen in the lung $(\times 100, H \& E)$.

\section{Discussion}


Nowadays, herbal remedies are considered in primary healthcare programs. In spite of various properties, their side effects still need to be investigated (1-3). The present study shows that systemic alterations can be induced by in-ovo inoculation of chick embryo, using the leafextraction of $O$. vulgare. The most important changes induced by the leaf-extract of $O$. vulgare was microscopic lesions. Various histopathological injuries were seen in the brain, liver, kidneys, heart, and lungs' tissues, and the severest lesion was noticed in embryos which received the high dose of the extract (equal/higher than $50 \mathrm{mg} / \mathrm{Kg}$ ).

The histopathologic alterations indicated that the chick embryo is susceptible to the application of $O$. vulgare leafextract during the embryonic development. Amongst the histopathological lesions, congestion and edema were noticed in the brain which has to be given attention, due to $O$. vulgare leaf-extract side effect on the central nervous system. Interestingly, histopathological injures were observed in embryos without any gross lesions, even the ones treated with a high dose of $O$. vulgare (50 and $100 \mathrm{mg}$ extract/Kg egg-weight). Thymol and carvacrol are the major biochemical in Origanum with proven antioxidant and antimicrobial properties (29). Carvacrol has shown to have anti-proliferative property in HeLa cells (29), but thymol has beneficial effects on the antioxidant features of the brain in rat (30). Thymol and carvacrol have also anti-inflammatory activity on human macrophages (THP-1) (31). The use of oregano's essential oils provides a promising perspective on the prevention of cell disorders (32), but its high concentration (higher than $30 \mu \mathrm{g} / \mathrm{mL}$ ) can cause a reduction in cell viability (31). Genotoxic effect of Origanum and carvacrol have been described elsewhere (33). Furthermore, Origanum toxicity on some animals and insects has been reported (34-37). For example, Nasr et al. (38) showed that $O$. vulgare caused significant changes in physiological parameters in diamondback moth. It was also shown that Origanum possessed antiangiogenic activity (39). Thus, it can be inferred that the congestion in the embryo is through its activity on the cardiovascular system. Different alterations have been reported after an application of Origanum compounds in animal models. Administration of aqueous extract of $O$. vulgare in a mouse model caused a retardation in the embryo development (40).

In this investigation, alterations were observed after inovo administration of $O$. vulgare leaf-extract, which could be the result of major or active chemical compounds present in this plant. Origanum phytochemical analyses exhibited various volatile and aroma organic compounds including linalool, ocimene, caryophyllene, germacrene, bisabolene, and spatulenol $(\mathbf{4 1}, \mathbf{4 2})$. Another hypothesis for the alterations induced by $O$. vulgare leaves-extract could be due to the apoptotic effect of this plant. For instance, Savini et al. (43) showed that $O$. vulgare could induce apoptosis in the colon cancer cells (caco2) of human. In addition of the $O$. vulgare active chemicals, other metabolites might also be correlated with the adverse histopathological effects. Furthermore, specific inherent activities of leaf-extract have been postulated to be associated with its effects. Therefore, new studies are warranted to discover $O$. vulgare biochemical composition and mechanisms in the embryo.

\section{Conclusion}

Histopathological lesions that had occurred in a dosedependent manner during $O$. vulgare administration suggest the susceptibility of chick embryo to the $O$. vulgare leaf-extract. Injures might be due to different pathways including the effects of chemical compounds, apoptotic effect, biochemicals, and mechanisms that contribute to the inherent properties. Therefore, more attention should be given to the toxic effects of $O$. vulgare during fetal development period.

\section{Acknowledgements}

The authors would like to thank the Vice-chancellor of Research at Shiraz University of Medical Sciences (grant No. 93-01-26-8050) for their financial support. The authors also wish to thank Mr. S. Hasanzadeh for his kind cooperation in tissue slide preparation and $\mathrm{Mr}$. H. Argasi at the Research Consultation Center (RCC) of Shiraz University of Medical Sciences for his invaluable assistance in editing this manuscript.

\section{Conflict of Interest}

Authors declared no conflict of interests.

\section{References}

1. Somani SJ, Modi KP, Majumdar AS, Sadarani BN. Phytochemicals and their potential usefulness in inflammatory bowel disease. Phytother Res. 2015;29(3):339-50. [DOI:10.1002/ptr.5271] [PMID]

2. Mahdavi N, Joukar S, Najafipour H, Asadi-Shekaari M. The promising effect of barberry (Zereshk) extract against experimental pulmonary microvascular remodeling and hypertension: A comparison with sildenafil. Pharm Biol. 2016;54(3):509-15. [DOI:10.3109/13880209.2015.1050676] [PMID]

3. Smeriglio A, Tomaino A, Trombetta D. Herbal products in pregnancy: experimental studies and clinical reports. Phytother Res. 2014;28(8):1107-16. [DOI:10.1002/ptr.5106] [PMID]

4. Sarikurkcu C, Zengin G, Oskay M, Uysal S, Ceylan R, Aktumsek A. Composition, antioxidant, antimicrobial and enzyme inhibition activities of two Origanum vulgare subspecies (subsp. vulgare and subsp. hirtum) essential oils. Indust Crops Prod. 2015;70:178-84. [DOI:10.1016/j.indcrop.2015.03.030] 
5. Koldas S, Demirtas I, Ozen T, Demirci MA, Behçet L. Phytochemical screening, anticancer and antioxidant activities of Origanum vulgare L. ssp. viride (Boiss.) Hayek, a plant of traditional usage. J Sci Food Agric. 2015;95(4):786-98. [DOI:10.1002/jsfa.6903] [PMID]

6. Coccimiglio J, Alipour M, Jiang Z-H, Gottardo C, Suntres Z. Antioxidant, antibacterial, and cytotoxic activities of the ethanolic Origanum vulgare extract and its major constituents. Oxid Med Cell Longev. 2016;2016: 1-8 [DOI:10.1155/2016/1404505] [PMID] [PMCID]

7. Zhang X-L, Guo Y-S, Wang C-H, et al. Phenolic compounds from Origanum vulgare and their antioxidant and antiviral activities. Food Chem. 2014;152:300-6. [DOI:10.1016/j.foodchem.2013.11.153] [PMID]

8. Sankar R, Dhivya R, Shivashangari KS, Ravikumar V. Wound healing activity of Origanum vulgare engineered titanium dioxide nanoparticles in Wistar Albino rats. J Mater Sci Mater Med. 2014;25(7):1701-8. [DOI:10.1007/s10856-014-5193-5] [PMID]

9. Han X, Parker TL. Anti-inflammatory, tissue remodeling, immunomodulatory, and anticancer activities of oregano (Origanum vulgare) essential oil in a human skin disease model. Biochimie Open. 2017;4:73-7. [DOI:10.1016/j.biopen.2017.02.005] [PMID] [PMCID]

10. Afarineshe Khaki MR, Pahlavan Y, Sepehri G, Sheibani V, Pahlavan B. Antinociceptive Effect of Aqueous Extract of Origanum vulgare L. in Male Rats: Possible Involvement of the GABAergic System. Iran JPharm Res. 2013;12(2):407-13.

11. Fournomiti M, Kimbaris A, Mantzourani I, Plessas S, Theodoridou I, Papaemmanouil V, et al. Antimicrobial activity of essential oils of cultivated oregano (Origanum vulgare), sage (Salvia officinalis), and thyme (Thymus vulgaris) against clinical isolates of Escherichia coli, Klebsiella oxytoca, and Klebsiella pneumoniae. Microbial Ecology in Health and Disease. 2015;26(1):23289. [DOI:10.3402/mehd.v26.23289] [PMID] [PMCID]

12. Araújo L, Araújo R, Serra J, Nascimento A. Chemical composition and susceptibility of oregano essential oil (Origanum vulgare L, Lamiaceae) on strains of Escherichia coli, Staphylococcus aureus and Salmonella choleraesuis. Boletim do Centro de Pesquisa e Processamento de Alimentos (Brazil). 2015. [DOI:10.5380/cep.v33i1.43808]

13. Orue N, García S, Feng P, Heredia N. Decontamination of Salmonella, Shigella, and Escherichia coli O157: H7 from leafy green vegetables using edible plant extracts. J Food Scie. 2013;78(2): 290-96. [DOI:10.1111/1750-3841.12016] [PMID]

14. Bakkali F, Averbeck S, Averbeck D, Idaomar M. Biological effects of essential oils-a review. Food Chem Toxicol 2008;46(2):446-75. [DOI:10.1016/j.fct.2007.09.106] [PMID]

15. Bowen I, Corrigan D, Cubbin I, de Smet P, Hänsel R, Sonnenborn U, et al. Adverse effects of herbal drugs 2: Springer Science \& Business Media; 2012.

16. Singroha R, Srivastava S, Chhikara P. Effect of Gentamicin on kidney in developing chicks. Eur Jl Anatomy. 2012;16(2):119 26.

17. Vergara MN, Canto-Soler MV. Rediscovering the chick embryo as a model to study retinal development. Neural Devel. 2012;7(1):22. [DOI:10.1186/1749-8104-7-22] [PMID] [PMCID]
18. Stern CD. The chick: a great model system becomes even greater. Devel Cell. 2005;8(1):9-17. https://doi.org/10.1016/S1534-5807(04)00425-3 [DOI:10.1016/j.devcel.2004.11.018]

19. Burt DW. Emergence of the chicken as a model organism: implications for agriculture and biology. Poultry Scie. 2007;86(7):1460-71. [DOI:10.1093/ps/86.7.1460] [PMID]

20. Farjadmand F, Eslami M, Sadighara P. Tomato leaves: The first report of malformation in chick embryos. Biharean Biologist. 2011;5(2):164-5.

21. Coşkun I, Çayan H, Yilmaz Ö, Taskin A, Tahtabiçen E, Samli HE. Effects of in-ovo pollen extract injection to fertile broiler eggs on hatchability and subsequent chick weight. Türk Tarım ve Doğa Bilimleri Dergisi. 2014;1(4):485-9.

22. Furness B, Hannaford A, Smith P, Tatchell A. Vogel's textbook of practical organic chemistry. 5nd edn ed. New York, USA: Logmans; 1989. 164-5 p.

23. Tavakkoli H, Derakhshanfar A, Noori Gooshki S. Toxicopathological lesions of fosfomycin in embryonic model. Eur J Expe Biol. 2014;4(2):63-71.

24. Tavakkoli H, Derakhshanfar A, Noori Gooshki S. A short preliminary experimental study on teratogenic effect of methenamine in embryonic model. Int $\mathbf{J}$ Adv Biological Biomedical Res. 2013;1(12):1523-8.

25. Reyes MR, Reyes-Esparza J, Ángeles OT, Rodríguez-Fragoso L. Mutagenicity and safety evaluation of water extract of Coriander sativum leaves. J food sci. 2010;75(1):T6-T12. [DOI:10.1111/j.1750-3841.2009.01403.x] [PMID]

26. Wang S, Zheng Z, Weng Y, et al. Angiogenesis and antiangiogenesis activity of Chinese medicinal herbal extracts. $\begin{array}{lll}\text { Life } & \text { scie. } & \text { 2004;74(20):2467-78. }\end{array}$ [DOI:10.1016/j.lfs.2003.03.005] [PMID]

27. Derakhshanfar A, Tavakkoli H. Evaluation of the Embryonic Pathological Lesions and Efficacy of Amantadine against H9N2 Influenza Virus Using Chicken Embryo Model. J Kerman Univ Med Scie. 2016;23(5):554-71.

28. Mosallanejad SS, Tavakkoli H, Salandari S. In Ovo Injection of Triaminohexanoic Acid in Fowl: Gross Investigation. Int J Adva Biol Biom Res. 2015;3(2): 139-44.

29. Mastelic J, Jerkovic I, Blažević I, Poljak-Blaži M, Borović S, Ivančić-Baće I, et al. Comparative study on the antioxidant and biological activities of carvacrol, thymol, and eugenol derivatives. J Agricul Food Chem. 2008;56(11):3989-96. [DOI:10.1021/jf073272v] [PMID]

30. Youdim KA, Deans SG. Effect of thyme oil and thymol dietary supplementation on the antioxidant status and fatty acid composition of the ageing rat brain. Br J Nut. 2000;83(1):8793. [DOI:10.1017/S000711450000012X]

31. Ocana-Fuentes A, Arranz-Gutierrez E, Senorans F, Reglero G. Supercritical fluid extraction of oregano (Origanum vulgare) essentials oils: anti-inflammatory properties based on cytokine response on THP-1 macrophages. Food Chem Toxicol. 2010;48(6):1568-75. [DOI:10.1016/j.fct.2010.03.026] [PMID]

32. Loizzo MR, Menichini F, Conforti F, et al. Chemical analysis, antioxidant, antiinflammatory and anticholinesterase activities of Origanum ehrenbergii Boiss and Origanum syriacum L. essential oils. Food Chem. 2009;117(1):174-80. [DOI:10.1016/i.foodchem.2009.03.095] 
33. Ipek E, Zeytinoglu H, Okay S, Tuylu BA, Kurkcuoglu M, Baser KHC. Genotoxicity and antigenotoxicity of Origanum oil and carvacrol evaluated by Ames Salmonella/microsomal test. Food Chem. 2005;93(3):551-6. [DOI:10.1016/j.foodchem.2004.12.034]

34. Yang Y-C, Lee SH, Clark JM, Ahn Y-J. Ovicidal and adulticidal activities of Origanum majorana essential oil constituents against insecticide-susceptible and pyrethroid/malathion-resistant Pediculus humanus capitis (Anoplura: Pediculidae). J Agric Food Chem. 2009;57(6):2282-7. [DOI:10.1021/jf803738z] [PMID]

35. Tayoub G, Alnaser A, Ghanem I. Toxicity of two essential oils from Eucalyptus globulus Labail and Origanum syriacum L. on larvae of khapra beetle. Int $\mathrm{J}$ Med Arom Plant. 2012;2(2):240-5.

36. Lahlou M. Potential of Origanumcompactum as a cercaricide in Morocco. Annals of Tropical Medicine \& Parasitology. 2002;96(6):587-93. [DOI:10.1179/000349802125001447] [PMID]

37. Tozlu E, Cakir A, Kordali S, Tozlu G, Ozer H, Akcin TA. Chemical compositions and insecticidal effects of essential oils isolated from Achillea gypsicola, Satureja hortensis, Origanum acutidens and Hypericum scabrum against broadbean weevil (Bruchus dentipes). Scientia Horticulturae. 2011;130(1):9-17 [DOI:10.1016/j.scienta.2011.06.019]

38. Nasr M, Sendi JJ, Moharramipour S, Zibaee A. Evaluation of Origanum vulgare L. essential oil as a source of toxicant and an inhibitor of physiological parameters in diamondback moth, Plutella xylustella L.(Lepidoptera: Pyralidae). J Saudi Society of Agricultural Sci. 2017;16(2):184-90. [DOI:10.1016/i.jssas.2015.06.002]

39. Bostancioğlu RB, Kürkçüoğlu M, Başer KHC, Koparal AT. Assessment of anti-angiogenic and anti-tumoral potentials of Origanum onites L. essential oil. Food Chem Toxicol. 2012;50(6):2002-8. [DOI:10.1016/j.fct.2012.03.074] [PMID]

40. Benavides V, D'Arrigo G, Pino J. Effects of aqueous extract of Origanum vulgare L.(Lamiaceae) on the preimplantational mouse embryos. Rev Per Biol. 2010;17(3): 381-84. [DOI:10.15381/rpb.v17i3.15]

41. Garcia M, Sanz J. Analysis of Origanum vulgare volatiles by direct thermal desorption coupled to gas chromatographymass spectrometry. J Chrom A. 2001;918(1):189-94. [DOI:10.1016/S0021-9673(01)00750-6]

42. Şahin F, Güllüce M, Daferera D, et al. Biological activities of the essential oils and methanol extract of Origanum vulgare ssp. vulgare in the Eastern Anatolia region of Turkey. Food Control. 2004;15(7):549-57. [DOI:10.1016/j.foodcont.2003.08.009]

43. Savini I, Arnone R, Catani MV, Avigliano L. Origanum vulgare induces apoptosis in human colon cancer caco2 cells. $\begin{array}{lll}\mathrm{Nu} & \mathrm{Can} & 2009 ; 61(3): 381-9 .\end{array}$ [DOI:10.1080/01635580802582769] [PMID]

\section{How to Cite This Article:}

\section{J Adv Med Biomed Res. 2019; 27 (120) :1-7}

